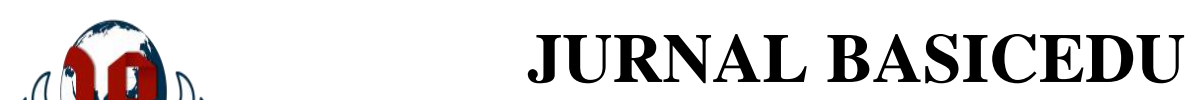

Volume 5 Nomor 4 Tahun 2021 Halaman 1700 - 1708

Research \& Learning in Elementary Education

https://jbasic.org/index.php/basicedu

PAHLAWAN

\title{
Penerapan Model PBL untuk Meningkatkan Keaktifan Peserta Didik dalam Pembelajaran Daring di Sekolah Dasar
}

\author{
Indha Yunitasari $^{1 凶}$, Agustina Tyas Asri Hardini $^{2}$ \\ Pendidikan Profesi Guru Sekolah Dasar, Universitas Kristen Satya Wacana, Indonesia ${ }^{1,2}$ \\ E-mail: 952020510@ student.uksw.edu ${ }^{1}$, tyas.asri@ staff.uksw.edu $^{2}$
}

\begin{abstract}
Abstrak
Tujuan penelitian ini adalah untuk meningkatkan keaktifan peserta didik setelah diterapkan model pembelajaran problem based learning di kelas 4 SDN Anggaswangi selama pembelajaran daring. Jenis penelitian ini penelitian tindakan kelas menggunakan model spiral, yang dilakukan dalam 2 siklus. Subjek penelitian adalah siswa kelas IV sebanyak 30 peserta didik yang terdiri dari 18 peserta didik laki-laki dan 12 peserta didik perempuan. Teknik pengumpulan data menggunakan teknik non tes, kemudian dilakukan analisis deskriptif kuantitatif dan kualitatif dari data yang diperoleh. Penerapan model problem based learning menunjukan hasil di antaranya dapat meningkatkan keaktifan peserta didik kelas IV SDN Anggaswangi terutama tema 6 selama pembelajaran daring. Hasil penelitian menunjukan bahwa pada siklus I terjadi peningkatan aktivitas peserta didik sebesar 90.16. Ini berarti bahwa hanya 1 peserta didik (3.3) memiliki tingkat keaktifan kurang. 18 peserta didik (60\%) memiliki kategori cukup, 8 peserta didik (26.7\%) aktif, dan 3 peserta didik (10\%) sangat aktif. Pada siklus II rata-rata keaktifan peserta didik meningkat menjadi 118.57. Artinya sebanyak 11 peserta didik (36.7\%) sangat aktif, 18 peserta didik (60\%) kriteria aktif, dan hanya 1 peserta didik (3.3\%) dalam kriteria cukup aktif. Dengan demikian melalui penerapan model pembelajaran problem based learning selama pembelajaran daring terbukti dapat meningkatkan keaktifan peserta didik kelas IV SDN Anggaswangi pada pembelajaran tematik tahun pembelajaran 2020/2021.
\end{abstract}

Kata Kunci: Keaktifan, problem based learning.

\begin{abstract}
This study aims to improve students' activeness after the problem-based learning model is applied in the fourth grade of SDN Anggaswangi during online learning. The type of this research is classroom action research using a spiral model, which is conducted in 2 cycles. The research subjects were 30 students of the fourth grade, that consist of 18 male students and 12 female students. The data collection technique was non-test techniques, then carried out quantitative and qualitative descriptive analysis of the data obtained. The Use of problem based learning model showed that it could enhance students' activeness in the fourth grade students of SDN Anggaswangi especially in the sixth topic during online learning. The result showed that in the first cycle, there was an enhancement on students' activity of 90.16. It means that only 1 student (3.3) had less activeness, 18 students (60\%) were in average, 8 students (26.7\%) were in active, and 3 students $(10 \%)$ were in very active category. In the second cycle, the student's average activeness enhanced to be 118.57. It means that 11 students (36.7\%) were very active, 18 students (60\%) were active, and only 1 student (3.3\%) was in average category. Thus, through the application of the problem based learning model during online learning, it is proven to be able to increase the activeness of the fourth grade students of SDN Anggaswangi in thematic learning for the academic year of 2020/2021.
\end{abstract}

Keywords: Activeness, problem based learning.

Copyright (c) 2021 Indha Yunitasari, Agustina Tyas Asri Hardini

$\triangle$ Corresponding author :

Email :952020510@student.uksw.edu

DOI : https://doi.org/10.31004/basicedu.v5i4.983

ISSN 2580-3735 (Media Cetak)

ISSN 2580-1147 (Media Online)

Jurnal Basicedu Vol 5 No 4 Tahun 2021

p-ISSN 2580-3735 e-ISSN 2580-1147 


\section{PENDAHULUAN}

Pembelajaran tematik terpadu menurut Kemendikbud adalah pembelajaran yang menggunakan topik untuk menghubungkan berbagai topik atau muatan secara bersama-sama yang dapat memberikan peserta didik pengalaman yang bermakna (Khoeriyah and Mawardi 2018). Selama pademi Covid 19, pembelajaran tematik komprehensif di sekolah dasar dilakukan secara daring atau tidak tatap muka secara langsung yang mana menerapkan pembelajaran daring dapat menjadi sarana bagi sekolah dan guru. Menteri Pendidikan Nadiem Makarim juga menegaskan bahwa pademi Covid 19 adalah bom di mana saat ini waktu yang tepat kebangkitan pendidikan Indonesia untuk lebih mengembangkan keterampilan belajar abad 21, melibatkan peserta didik dalam pembelajaran dapat memperoleh pengalaman praktis, tanggap beradaptasi melalui penggunaan aplikasi yang berbasis internet (Prayogi and Estetika 2019).

Proses pembelajaran sekarang bisa dilakukan di manapun atau tidak hanya dapat dilakukan di sekolah saja. Walaupun demikian, dalam prosesnya Kurikulum 2013 harus menampakkan proses pembelajaran yang memungkinkan peserta didik berlatih mengembangkan keaktifan dalam menemukan konsep sendiri berdasarkan pengalamanya. Muara keaktifan peserta didik pada akhirnya adalah hasil belajarnya. Namun kenyataannya proses pembelajaran yang terjadi di SDN Anggaswangi belum menerapkan model pembelajaran yang mampu meningkatkan keaktifan peserta didik selama pembelajaran online atau daring. Hasil pengamatan awal menunjukkan bahwa peserta didik kelas IV SDN Anggaswangi tingkat keaktifan siswa selama pembelajaran daring masih rendah, serta peserta didik memang sudah merata yang memiliki kecanggihan smartphone namun kenyataannya mereka lebih aktif membuka permainan yang berbau tidak efektif untuk dipelajari hal tersebut berdampak pada semangat keaktifan belajar peserta didik.

Pengamatan awal dari informasi yang didapat atau diperoleh dari wawancara dengan guru kelas IV diantaranya proses pembelajaran siswa kelas IV SDN Anggaswangi selama daring atau ketika melakukan interaksi-interaksi pembelajaran bersama guru, dan diwaktu sama disertai secara kebersamaan pula menggunakan group whatsapp, di situ terlihat keterlibatan atau interaksi-interaksi peserta didik pada saat pembelajaran masih belum nampak, yang dikarenakan pembelajaran lebih terfokus teoritis atau minim sekali praktik karena dimana kita ketahui selama ini, yaitu Covid 19 yang tidak memungkinkan adanya interaksiinteraksi secara langsung dengan peserta didik. Hal ini didukung dengan oleh data dari 30 peserta didik kelas IV, terlihat hanya 2 peserta didik (6.7\%) yang memiliki kriteria aktif, lalu 9 peserta didik (30\%) memiliki kriteria cukup aktif, kemudian 12 peserta didik (40\%) kriteria kurang aktif, dan tersisa 7 peserta didik (63.33\%) sangat tidak aktif. Menindaklanjuti data sebelum siklus dapat terlihat nilai rata-rata keaktifan peserta didik hanya 72.36 artinya dalam kriteria sangat tidak aktif.

Berbagai upaya peningkatan keaktifan telah dilakukan berkali-kali, namun belum ada hasil yang dicapai, pasalnya sekolah belum menerapkan model pembelajaran yang tepat dan hanya menggunakan aplikasi komunikasi group whatsapp yang belum memungkinkan untuk meningkatkan keterlibatan peserta didik atau keaktifan peserta didik sekaligus kemampuan peserta didik dalam mencapai hasil belajar selama pembelajaran daring atau online. Melihat berbagai penerapan model problem based learning dalam melakukan berbagai penelitian tindakan kelas dapat meningkatkan keterlibatan peserta didik atau keaktifan peserta didik. Untuk meningkatkan proses keaktifan peserta didik dan kemampuan hasil belajarnya, maka dari itu akan digunakan model pembelajaran problem based learning berbantuan aplikasi Zoom.

(Mungzilina, Kristin, and Anugraheni 2018) mengemukakan bahwa salah satu penilaian dalam proses pembelajaran yaitu melihat antusiasme peserta didik mengikuti proses pembelajaran yang mana seluruh aktivitas-aktivitasnya yaitu peserta didik terlibat dalam partisipasi aktif. Oleh karena itu, peserta didik bukan hanya sebagai penerima sumbangan guru, tetapi juga berperan di dalam aktivitas secara mental dan fisik. Menurut pendapat (Pramudya, Kristin, and Anugraheni 2019) bahwa dapat dikatakan aktif jika dalam kegiatan mengajar yaitu dengan melibatkan peserta didik selama mengikuti proses pembelajaran atau selama 
1702 Penerapan Model PBL untuk Meningkatkan Keaktifan Peserta Didik dalam Pembelajaran Daring di Sekolah Dasar - Indha Yunitasari, Agustina Tyas Asri Hardini

DOI: https://doi.org/10.31004/basicedu.v5i4.983

pembelajaran berlangsung. Sedangkan menurut pendapat (Nurhayati 2020) mendeskripsikan bahwa keaktifan adalah situasi atau hal yang dipelajari peserta didik secara aktif. Dengan demikian dari keterlibatan peserta didik dalam proses pembelajaran tentunya dapat dilihat melalui bentuk-bentuk aktivitas peserta didik di dalam pembelajaran dimana berdiskusi menjadi hal yang penting lalu kemudian mendengarkan argumen, lalu memecahkan masalah, keterlibatan secara aktif juga dalam melaksanakan atau memperhatikan tugas dari guru, setelah itu membuat sebuah laporan, dan terakhir mampu menampilkan atau mempresentasikan hasil belajar peserta didik.

Berdasarkan pendapat para ahli, dapat disimpulkan bahwa peserta didik dapat dikatakan aktif yaitu apabila terlihat antusiasme, atau bentuk-bentuk aktivitas yang melibatkan peserta dalam kelas atau selama pembelajaran berlangsung, diantaranya terlihat mendengarkan berbagai argumen yang disampaikan teman, saling berdiskusi, bersama memecahkan problem atau masalah, keterlibatan dalam memperhatikan guru ketika memaparkan tugas, sedia menuliskan hal-hal atau laporan, akhir tindakan yaitu mempresentasikan hasil tulisan atau laporan yang telah dibuat.

Adapun indikator keberhasilan penilaianya yaitu melihat sejauh mana keterlibatan, keaktifan peserta didik selama proses belajar mengajar. Menurut Sudjana dalam (Wibowo 2016) menjabarkan bahwa ada 8 indikator keaktifan peserta didik, diantaranya: (1) Berpartisipasi dalam pelaksanaan berbagai tugas (2) Terlibat langsung pemecahan masalah (3) Bertanya kepada peserta atau guru apakah mereka tidak memahami masalah yang dihadapi (4) Berusaha mencari segala macam informasi yang dibutuhkan dalam menyelesaikan masalah (5) Melakukan diskusi antar kelompok sesuai bimbingan guru (6) Evaluasi kemampuan dan hasil yang diperolehnya (7) Melatih diri dalam memecahkan masalah serupa (8) Berkesempatan menerapkan apa yang telah didapat dalam menyelesaikan tugas atau masalah yang dihadapi. Dapat disimpulkan dari indikator yang telah diuraikan, bahwa aktivitas peserta-peserta didik dapat dilihat aktivitas visualnya atau menyimak, mendengarkan segala instruksi, diskusi, persiapan peserta didik, bertanya, keberanian peserta didik mengutarakan pendapatnya, dan mental-mental dalam memecahkan segala persoalan yang dihadapi.

Model pembelajaran juga sangat berpengaruh dalam proses belajar atau mengaktifkan keterlibatan peserta didik selama pembelajaran berlangsung. Maka dari itu diperlukan atau pemberlakukan model pembelajaran yang mampu mengaktifkan peserta didik yaitu problem based learning. Titik awal pembelajaran problem based learning di mana terciptanya suasana belajar yang mendukung dalam kegiatan mengaktifkan atau memperlakukan peserta didik sebagai figur utama dalam pembelajaran yang menumbuhkan kemampuan berpikir mandiri peserta didik, menghargai kegiatan yang sedang berlangsung, yang terakhir yaitu memupuk rasa kepercayaan dirinya (Fristadi and Bharata 2015). Menurut pendapat (Alwafi Ridho Subarkah 2018) mengungkapkan bahwa model problem based learning itu terlihat apabila peserta didik dapat melakukan segala aktivitasnya yaitu kebebasan peserta didik mengidentifikasi permasalahan, lalu sekaligus memecahkan masalah yang dihadapi baik itu secara kelompok maupun pengerjaan secara mandiri dengan melalui tahapantahapan yang mana bertujuan agar peserta didik meningkat pola berpikir kritisnya atau lebih memahami dalam meningkatkan masalahnya atau berpikir kritis peserta didik. Menambahkan pendapat dari (Termini et al. 2020) bahwa model problem based learning adalah model pembelajaran yang berkesinambungan atau beranjak dari masalah-masalah yang terjadi di dunia nyata, yang mana peserta didik mempelajari sesuai sub topik. Menurutnya juga pembelajaran seperti yang ia gambarkan ini bahkan akan membuat peserta aktif, terlibat secara langsung membangun pengetahuanya atau menciptakan pengalamanya sendiri.

Berdasarkan pengertian yang dijabarkan oleh para ahli, dapat disimpulkan bahwa model problem based learning membantu untuk menciptakan suasana, yang mana segala aktivitasnya melibatkan peserta didik itu sendiri yang berguna memupuk kepercayaan dirinya, menambah atau meningkatkan pola berpikirnya, dan mengembangkan atau membangun pengetahuan-pengetahuanya sendiri yang berkesinambungan atau beranjak dari problem di dunia nyata. 
1703 Penerapan Model PBL untuk Meningkatkan Keaktifan Peserta Didik dalam Pembelajaran Daring di Sekolah Dasar - Indha Yunitasari, Agustina Tyas Asri Hardini

DOI: https://doi.org/10.31004/basicedu.v5i4.983

Di dalam model problem based learning terdapat sintak yang dapat menunjang keberhasilan model tersebut yang dipaparkan oleh (Vera and Astuti 2019) antara lain: (1) penyajian terhadap masalah yang harus dipecahkan peserta didik (2) mengatur pembelajaran peserta didik (3) membimbing peserta didik dalam pelaksanaan eksperimen (4) mengembangkan karya berupa video, atau laporan (5) menganalisis serta mengevaluasi proses pembelajaran. Menurut pendapat Rusman dalam (Dayeni, Irawati, and Yennita 2017) model problem based learning diantaranya ada 5 tahapan dapat diuraikan (1) orientasi masalah peserta didik dalam peranya guru akan mendorong peserta didik agar mengajukan pertanyaan yang berhubungan seputar materi atau topik yang telah ditentukan. (2) peserta didik diorganisir untuk belajar artinya guru membantu peserta didik mendefinisikan tugas atau mengorganisasikan tugas belajarnya. (3) membimbing peserta didik dalam mencari atau mengumpulkan informasi nya sendiri yang didapatkan melalui pengalaman. (4) menyajikan karyanya atau mempresentasikan karya yang telah dibuat oleh peserta didik. (5) dan terakhir masalah dianalisis dan dievaluasi melalui refleksi dari guru.

Penggunaan model problem based learning dikuatkan pula dari penelitian yang sudah pernah menggunakan model pembelajaran problem based learning pada keaktifan peserta didik dalam penelitian oleh (Dewi, Sumarmi, and Amirudin 2016) bahwa dalam penelitianya menunjukan adanya peningkatan keaktifan peserta didik dengan menggunakan Problem Based Learning di mana skor rerata dari siklus I hanya di level cukup yaitu 56.20 sampai 83.70 di level sangat tinggi siklus II.

Penelitian yang dilakukan oleh (Dhita Fitriani, Nurwidodo 2019) juga memaparkan terjadi peningkatan keaktifan berpikir kritis dan hasil belajar peserta didik dalam penggunaan model problem based learning yang terus meningkat dari 39 peserta didik di siklus I sebanyak 29 peserta didik kategori aktif. Pada siklus II sebanyak 36 peserta didik yang aktif, dan diikuti dengan meningkatnya hasil belajar peserta didik.

Penelitian lain yang dilakukan (Misla and Mawardi 2020) menunjukan bahwa dengan menggunakan model problem based learning lebih unggul dalam meningkatkan aktivitas berpikir kritis peserta dalam menyelesaikan soal matematika dengan rata-rata nilai 86.171.

Walaupun dalam penelitian (Dhita Fitriani, Nurwidodo 2019) dan (Misla and Mawardi 2020) terdapat perbedaan keterampilan, namun dapat dibuktikan bahwa dalam penerapan problem based learning terbukti ampuh meningkatkan keaktifan dan kemampuan berpikir kritis serta hasil belajar peserta didik.

Maka dari itu, dalam penelitian ini dituliskan akankah model problem based learning mampu meningkatkan meningkatkan keaktifan peserta didik kelas IV SDN Anggaswangi selama daring. Seiring dengan tujuan dalam pembelajaran ini adalah meningkatkan keaktifan peserta didik melalui pembelajaran daring dengan model problem based learning kelas IV SDN Anggaswangi Semester II Tahun Pelajaran 2020/202I.

\section{METODE PENELITIAN}

Metode Penelitian ini dikategorikan jenis penelitian tindakan kelas yang menggunakan model spiral yang ditegaskan oleh Kemmis \& Mc Taggart dimana pada tiap siklus terbagi sebanyak empat tahapan, yaitu perencanaan-pelaksanaan-observasi-terakhir refleksi (Frianto, Relmasira, and Hardini 2018).

Setting penelitian tindakan kelas dilakukan pada siswa kelas IV SDN Anggaswangi semester dua tahun pembelajaran 2020/2021 dimana pada tahun ini penelitian dilaksanakan pada masa pademi Covid 19, dengan topik yang dipelajari yaitu Cita-citaku Tema 6. Jumlah peserta didik sebanyak 30 peserta didik, yang terdiri dari 18 peserta didik laki-laki dan 12 peserta didik perempuan.

Variabel dalam PTK terdiri dari variabel bebas yaitu model pembelajaran problem based learning, sementara variabel terikat perubahan keaktifan peserta didik setelah diberlakukan model problem based learning selama pembelajaran daring. 
1704 Penerapan Model PBL untuk Meningkatkan Keaktifan Peserta Didik dalam Pembelajaran Daring di Sekolah Dasar - Indha Yunitasari, Agustina Tyas Asri Hardini

DOI: https://doi.org/10.31004/basicedu.v5i4.983

Adapun Teknik pengumpulan data menggunakan teknik non tes dengan lembar observasi sebagai instrumennya. Teknik analisis data menggunakan analisis deskriptif kuantitatif dan kualitatif dari data yang diperoleh. Sebelum itu, instrumen pernyataan terlebih dahulu dilakukan uji reliabilitas, dengan dijabarkan syarat koefisien reliabilitas berdasarkan nilai alfa dapat diinterpretasikan menurut Wardani (Safitri and Endarini 2020) apabila indeks korelasi antara nilai $0.80-1.00$ dalam kategori tinggi reliable. Hasil uji reliabilitas pernyataan lembar observasi menunjukan nilai Cronbach's Alpha sebesar 0.932 berarti reliabilitasnya tinggi dari 34 item yang diuji. Kemudian dilakukan analisis deskriptif kuantitatif dan kualitatif dari data yang diperoleh.

Data kuantitatif dikategorikan angka atau nilai (Slameto 2015). Data didapat dari hasil non pengujian lembar observasi dan rubrik penilaian tugas. Setelah itu, data kuantitatif dianalisis menggunakan deskriptif komparatif atau dilakukan perbandingan pada kondisi sebelum siklus, siklus satu dan siklus dua bertujuan salah satunya untuk mengetahui meningkat atau tidak meningkatnya keaktifan dan hasil belajarnya setiap siklus dalam pembelajaran daring. Adapun indikator keberhasilan keaktifan dapat dikatakan jika rata-rata kreativitas peserta didik dalam kategori aktif atau telah berhasil ditingkatkan menjadi $70 \%$.

\section{HASIL DAN PEMBAHASAN}

Bab ini akan mendeskripsikan hasil analisis dan data penelitian tentang keaktifan dan hasil belajar tematik pada peserta didik kelas IV SDN Anggaswangi yang menerapkan model problem based learning pada tematik topik Cita-citaku Tema 6 muatan KD Bahasa Indonesia: (3.6) Menggali isi dan amanat puisi yang disajikan secara lisan dan tulis (4.6.) Melisankan puisi hasil karya dengan lafal, intonasi, dan ekspresi yang tepat sebagai bentuk ungkapan diri. Sedangkan pada muatan KD IPA: (3.2) Membandingkan siklus hidup hewan dengan mengaitkan upaya pelestarianya. KD (4.2) membuat skema siklus hidup serta upaya pelestarianya yang mana dalam pelaksanaan pembelajaran dilaksanakan dalam 2 siklus.

Sebelum penelitian pada siklus I, dilakukan penyampaian rencana kegiatan pelaksanaan pembelajaran sebagai berikut: (1) menyusun menyusun RPP dengan topik pembelajaran sesuai dengan KI, KD yang telah ditentukan pada bulan Februari 2021 dengan pembelajaran secara daring melalui zoom dengan menggunakan model pembelajaran problem based learning (2) menyusun lembar observasi untuk mengetahui segala aktivitas peserta didik yang terdiri 8 indikator keaktifan selama tindakan pembelajaran berlangsung dengan model pembelajaran problem based learning dan disertai penyusunan lembar observasi untuk guru (3) terakhir penyampaian rencana kegiatan dalam pelaksanaanya kepada guru SDN Anggaswangi. Setelah itu, dalam pelaksanaan dilakukan secara daring dengan setiap siklus dilakukan tiga kali pertemuan, yang artinya pembelajaran virtual tatap muka menggunakan aplikasi zoom sebanyak dua kali pertemuan, kemudian dilanjutkan satu pertemuan terakhir untuk memberikan link soal evaluasi, jadi total ada sebanyak 3 kali pertemuan.

Pada tahap sebelum penerapan model pembelajaran problem based learning, diketahui rata-rata nilai peserta didik yaitu hanya 72.36 dalam kriteria kurang aktif, artinya hanya 2 peserta didik (6.7\%) diantara 30 peserta didik yang memiliki kriteria aktif. Disusul hanya 9 peserta didik (30\%) memiliki kriteria cukup aktif, dan sebanyak 12 peserta didik (40\%) kriteria keaktifan yaitu kurang aktif, dan peserta didik yang sangat tidak aktif yaitu sebanyak 7 peserta didik (23.3).

Sambung siklus I, setelah diterapkan dengan model problem based learning terjadi peningkatan keaktifan. Hal ini terjadi karena pada kegiatan pada siklus I sesuai dengan rencana pembelajaran daring menggunakan model pembelajaran problem based learning. Keaktifan peserta didik di siklus ini memiliki rata-rata 96.06 yang artinya hanya 1 peserta (3.3) memiliki tingkat keaktifan kurang, 18 peserta didik (60\%) yaitu kriteria cukup memiliki keaktifan, sedangkan peserta didik yang aktif sebanyak 8 peserta didik (26.7\%), 
1705 Penerapan Model PBL untuk Meningkatkan Keaktifan Peserta Didik dalam Pembelajaran Daring di Sekolah Dasar - Indha Yunitasari , Agustina Tyas Asri Hardini

DOI: https://doi.org/10.31004/basicedu.v5i4.983

dan ada 3 peserta didik (10\%) memiliki kereaktifan sangat aktif setelah diterapkan dengan model problem based learning.

Pada siklus II, rata-rata keaktifan peserta didik mencapai 118.57 dalam kriteria akif, artinya dari 30 peserta didik tidak ada yang memiliki keaktifan kurang. Sebanyak 11 peserta didik (36.7\%) sangat aktif, dan 18 peserta didik $(60 \%)$ kriteria aktif, dan yang terakhir hanya 1 peserta didik (3.3\%) dalam kriteria cukup aktif. Pada siklus II peserta didik sudah mahir dalam penggunaan aplikasi zoom, sehingga makin meningkatnya keaktifan peserta dalam kegiatan pembelajaran berbasis masalah, berdiskusi, saling mengutarakan pendapatnya dalam memecahkan masalah.

Berdasarkan hasil yang telah disebutkan diatas dapat disimpulkan bahwa aktif dan tidak aktifnya peserta didik diukur dengan menggunakan rubrik dengan cara mencentang indikator yang tersedia yaitu skor (0) Sangat tidak aktif (1) Tidak aktif (2) Keaktifan cukup (3) Aktif (4) Sangat aktif. Selain itu, lembar observasi yang dilakukan guru juga memperkuat nilai dari keaktifan peserta didik.

Berikut gambaran perbandingan tabel dan diagram sebelum diberi perlakukan dengan model problem based learning dan sesudah siklus satu dan siklus dua dalam tabel 1 dan gambar 1.

Tabel 1. Keaktifan Pembelajaran Daring Kelas IV SDN Anggaswangi dengan Model problem based learning

\begin{tabular}{|c|c|c|c|c|}
\hline Perlakuan & Kriteria & $\begin{array}{c}\text { Nilai } \\
\text { rata-rata }\end{array}$ & $\begin{array}{c}\text { Nilai } \\
\text { Tertinggi }\end{array}$ & $\begin{array}{c}\text { Nilai } \\
\text { Terendah }\end{array}$ \\
\hline $\begin{array}{l}\text { Pra } \\
\text { siklus }\end{array}$ & $\begin{array}{l}\text { Keaktifan } \\
\text { kurang }\end{array}$ & 72,36 & 105 & 60 \\
\hline Siklus I & $\begin{array}{l}\text { Keaktifan } \\
\text { cukup }\end{array}$ & 96,06 & 109 & 80 \\
\hline Siklus II & Aktif & 118,36 & 130 & 100 \\
\hline
\end{tabular}

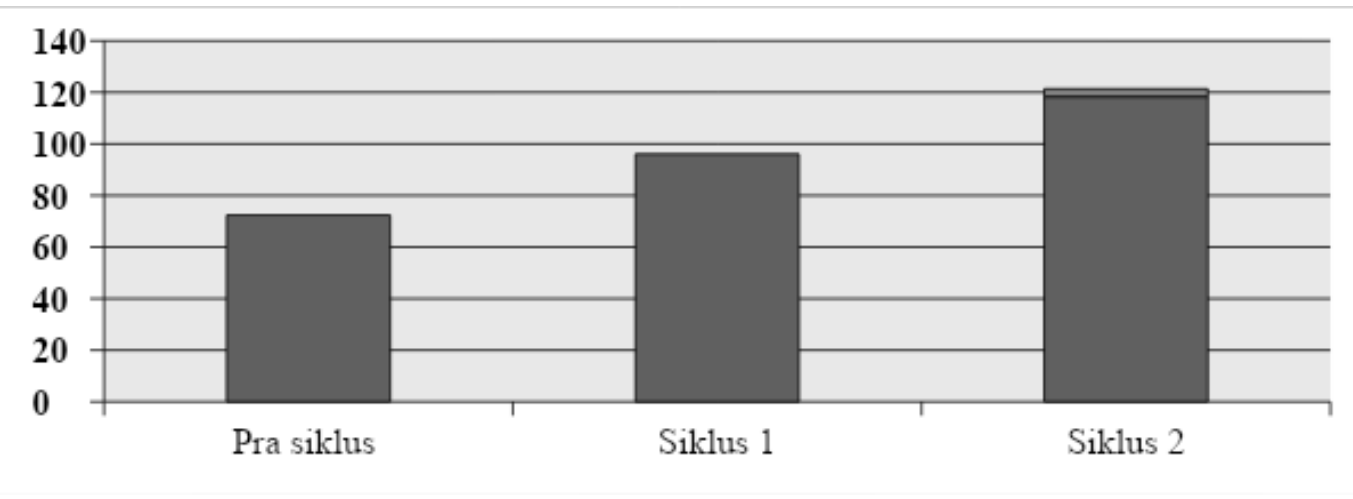

\section{Gambarl 1. Diagram Keaktifan Pembelajaran Daring Kelas IV SDN Anggaswangi dengan Model problem based learning}

Hasil penelitian yang dilakukan pada peserta didik pada peserta kelas IV SDN Anggaswangi selama pembelajaran daring dengan menggunakan model problem based learning dari sebelum siklus sampai siklus I dan siklus II terlihat adanya peningkatan pada keaktifan peserta didik dalam proses pemecahan masalahnya, diikuti dengan meningkatnya kemampuan kecakapan berdiskusi saat pembelajaran di zoom berlangsung.

Peningkatan keaktifan dilihat dari data hasil observasi yang menunjukan adanya peningkatan keaktifan peserta didik sebelum siklus, siklus I dan siklus II yang dilakukan oleh 4 observer. Jadi dapat disimpulkan bahwa dengan menggunakan model pembelajaran problem based learning ampuh untuk meningkatkan keaktifan peserta didik pada pembelajaran tematik. 
1706 Penerapan Model PBL untuk Meningkatkan Keaktifan Peserta Didik dalam Pembelajaran Daring di Sekolah Dasar - Indha Yunitasari, Agustina Tyas Asri Hardini

DOI: https://doi.org/10.31004/basicedu.v5i4.983

Pada saat sebelum siklus, rata-rata keaktifan sebelum diterapkan model pembelajaran problem based learning ketahui rata-rata keaktifan peserta didik yaitu hanya 72.36 dengan kategori kurang aktif, nilai tertinggi 105 dan nilai terendah 60. Setelah penggunaan model pembelajaran problem based learning pada siklus I, terjadi peningkatan keaktifan namun belum mencapai indikator kinerja yang telah ditentukan oleh peneliti. Hasil menunjukan rata-rata keaktifan peserta didik yaitu 96.06 dengan kategori cukup aktif, mendapat nilai tertinggi 109 dan nilai terendah 80 .

Siklus II terlihat adanya peningkatan keaktifan peserta didik dengan rata-rata sebesar 118.57, dengan nilai tertinggi sebesar 130, dan memiliki nilai terendah 100. Sebanyak 11 peserta didik (36.7\%) sangat aktif, dan 18 peserta didik (60\%) kriteria aktif, dan yang terakhir hanya 1 peserta didik (3.3\%) dalam kriteria cukup aktif. Pada tahap siklus II keaktifan peserta didik memiliki kriteria aktif, yang artinya sudah sesuai dengan indikator keberhasilan yang ditetapkan. Pada pelaksanaan tahap II peserta didik sudah percaya diri dalam menyatakan persetujuan nya, mempresentasikan laporan hasil pekerjaanya, aktif berpartisipasi dalam berkomentar kepada hasil karya teman yang ditampilkan guru ketika pembelajaran melalui zoom berlangsung, dan dalam kegiatan penutup peserta didik mampu merefleksikan materi yang telah dipelajari. Jadi setelah penerapan model pembelajaran problem based learning pada peserta didik dalam proses belajar dapat meningkatkan kriteria keaktifan yang semula keaktifan peserta didik kurang menjadi aktif.

Hal ini selaras dengan penelitian yang dilakukan oleh (Mungzilina, Kristin, and Anugraheni 2018) bahwa model pembelajaran problem based learning efektif dan inovatif meningkatkan presentase aktivitas keaktifan peserta didik dengan topik tematik kurikulum 2013. Dalam prosesnya penelitian ini bertujuan guna meningkatkan keaktifan peserta didik kelas IV SDN Anggaswangi dalam pembelajaran daring dengan model belajar problem based learning yang terbagi dalam 2 kegiatan.

Penelitian ini diperkuat dengan penelitian yang dilakukan (Siswa 2018), menunjukan keaktifan peserta didik yang dalam proses pembelajaran diterapkan model problem based learning hasilnya terbukti dari lembar observasi keaktifan peserta dengan persentase $70 \%$ siklus I meningkat menjadi $72.5 \%$ disiklus II. Begitu pula hasil penelitian yang dilakukan oleh (Mungzilina, Kristin, and Anugraheni 2018) menerangkan bahwa penggunaan model pembelajaran problem based learning mampu meningkatkan aktivitas berbagai keaktifan peserta didik dan hasil belajar peserta didik.

Kemudian penelitian yang telah dilakukan (Chanifah, Relmasira, and Hardini 2019) tentang penerapan model Problem Based Learning untuk meningkatkan kemampuan berpikir kritis sekaligus hasil belajar, menunjukan adanya kenaikan. Memang dalam penelitian (Chanifah, Relmasira, and Hardini 2019) keterampilan yang diteliti berbeda, namun dalam penelitiannya membuktikan dengan menggunakan model Problem Based Learning dapat meningkatkan kemampuan berpikir kritis dan hasil belajar yang dapat dilihat dari tabel dan diagram. Selanjutnya penelitian yang dilakukan oleh (Ismiyono 2020) memaparkan adanya peningkatan keaktifan aktivitas peserta didik dari sebelum siklus, setelah siklus satu dan dua, antara lain; mendengarkan instruksi, bertanya, berdiskusi dan menyatakan pendapat yang dilakukan secara daring menggunakan aplikasi zoom.

Keunggulan penelitian dalam menggunakan model problem based learning yaitu peserta didik belajar untuk memecahkan masalah secara individu maupun kelompok dalam pembelajaran tematik. Dalam proses pembelajaran peserta didik terlihat pada siklus 2 peserta didik sudah mahir dalam penggunaan aplikasi zoom, sehingga makin meningkatnya keaktifan peserta dalam berdiskusi, saling mengutarakan pendapatnya, percaya diri dalam mempresentasikan laporan hasil pekerjaanya, aktif berpartisipasi dalam mengomentari hasil karya teman yang ditampilkan guru ketika pembelajaran melalui zoom berlangsung, dan dalam kegiatan penutup peserta didik mampu merefleksikan materi yang telah dipelajari. Keaktifan peserta didik diukur dengan menggunakan rubrik dengan cara mencentang indikator yang tersedia yaitu skor (0) Sangat tidak aktif (1) Tidak aktif (2) Keaktifan cukup (3) Aktif (4) Sangat aktif. Selain itu, lembar observasi yang dilakukan guru juga memperkuat nilai dari keaktifan peserta didik. Dengan teknik pengolahan data menggunakan PAP tipe 1 
1707 Penerapan Model PBL untuk Meningkatkan Keaktifan Peserta Didik dalam Pembelajaran Daring di Sekolah Dasar - Indha Yunitasari, Agustina Tyas Asri Hardini

DOI: https://doi.org/10.31004/basicedu.v5i4.983

untuk mengetahui rerata kelas mengenai nilai keaktifan yang diperkuat juga dengan pengamatan melalui lembar observasi yang dilakukan oleh guru. Kegiatan wawancara dengan guru juga dilakukan, yang berguna untuk menunjang hasil yang diperoleh dari upaya peningkatan keaktifan peserta didik dengan model pembelajaran problem based learning dalam pembelajaran tematik melalui pembelajaran daring.

\section{KESIMPULAN}

Berdasarkan hasil Penelitian Tindakan Kelas IV di SDN Anggaswangi dengan menerapkan model problem based learning untuk topik yang dipelajari yaitu Cita-citaku Tema 6 melalui pembelajaran daring, dapat disimpulkan bahwa model problem based learning terbukti dapat meningkatkan keaktifan pada aktivitas pembelajaran daring menunjukan tingkat keaktifan peserta didik baik siklus satu maupun siklus kedua telah terjadi peningkatan. Hal tersebut terlihat pada tabel dan diagram perbandingan keaktifan peserta didik yang semula rata-rata aktivitas peserta didik pada siklus sebelumnya yaitu pada kategori aktivitas rendah yang semula 77.86 pada siklus pertama terjadi kenaikan kategori cukup aktif yaitu 90.16 dan dilanjutkan siklus kedua adanya peningkatan kembali yaitu keaktifan peserta didik dengan rata-rata 118.57. Saran berdasarkan hasil penelitian yang telah dilakukan bahwa model problem based learning efektif untuk pembelajaran secara daring melalui aplikasi zoom maupun dalam pembelajaran daring melalui grup whatsapp karena peserta didik terlatih menghadapi masalah, mendiskusikan rencana pemecahanya, memecahkan masalah, dan tanggap akan permasalahan yang dihadapi. Selain dapat meningkatkan keaktifan aktivitasnya, juga dapat dilakukan penelitian model problem based learning dalam pembelajaran daring untuk mengetahui peningkatan hasil belajar siswa.

\section{UCAPAN TERIMA KASIH}

Dengan ini penulis mengucapkan terima kasih kepada Ibu Agustina Tyas Asri Hardini,S.Pd.,M.Pd. serta Bapak Mus Dwi Aryanto, S.Pd. SD dan tak lupa SDN Anggaswangi yang telah membantu kami sehingga penulis dapat menyelesaikan penelitian ini.

\section{DAFTAR PUSTAKA}

Alwafi Ridho Subarkah. 2018. “No Title空間像再生型立体映像の 研究動向.” Nhk技研 151 (2): 10-17.

Chanifah, Miftichatun, Stefanus Christian Relmasira, And Agustina Tyas Asri Hardini. 2019. "Upaya Meningkatkan Kemampuan Berpikir Kritis Dan Hasil Belajar Pada Pembelajaran Matematika Menggunakan Model Pembelajaran Problem Based Learning Pada Siswa Kelas V Sd." Jurnal Basicedu 3 (1): 163-68. Https://Doi.Org/10.31004/Basicedu.V3i1.96.

Dayeni, Fitri, Sri Irawati, And Yennita Yennita. 2017. "Upaya Meningkatkan Motivasi Dan Hasil Belajar Siswa Melalui Model Problem Based Learning." Diklabio: Jurnal Pendidikan Dan Pembelajaran Biologi 1 (1): 28-35. Https://Doi.Org/10.33369/Diklabio.1.1.28-35.

Dewi, Sari, Sumarmi Sumarmi, And Ach Amirudin. 2016. "Penerapan Model Pembelajaran Problem Based Learning Untuk Meningkatkan Keaktifan Dan Keterampilan Sosial Siswa Kelas V Sdn Tangkil 01 Wlingi." Jurnal Pendidikan - Teori, Penelitian, Dan Pengembangan 1 (3): 281-88.

Dhita Fitriani, Nurwidodo, Elok Catur Wilujeng. 2019. “Jurnal Basicedu.” Jurnal Basicedu 3 (1): 208-13.

Frianto, Okta, Stefanus C Relmasira, And Agustina Tyas Asri Hardini. 2018. "Meningkatkan Kemampuan Pemecahan Masalah Matematika Melalui Penerapan Model Pembelajaran Problem Based Learning (Pbl) Berbantuan Media Realia Pada Siswa Kelas Iv Sd.” International Journal Of Elementary Education 2 (4): 348. Https://Doi.Org/10.23887/Ijee.V2i4.16115. 
1708 Penerapan Model PBL untuk Meningkatkan Keaktifan Peserta Didik dalam Pembelajaran Daring di Sekolah Dasar - Indha Yunitasari , Agustina Tyas Asri Hardini

DOI: https://doi.org/10.31004/basicedu.v5i4.983

Fristadi, Restu., And Haninda. Bharata. 2015. "Meningkatkan Kemampuan Berpikir Kritis Siswa Dengan Problem Based Learning." Seminar Nasional Matematika Dan Pendidikan Matematika Uny, 597-602.

Ismiyono. 2020. "Upaya Peningkatan Hasil Belajar Siswa Dalam Pembelajaran Daring Melalui Penerapan Model Problem Based Learning Siswa Kelas Iv Sd Negeri Sambeng Tahun 2020 / 2021 ” 1 (3): 63-67. Http://Journal.Kualitama.Com/Index.Php/Jkp/Article/View/10/25.

Khoeriyah, Ni'matul, And Mawardi Mawardi. 2018. "Penerapan Desain Pembelajaran Tematik Integratif Alternatif Berbasis Kearifan Lokal Untuk Meningkatkan Hasil Dan Kebermaknaan Belajar." Mimbar Sekolah Dasar 5 (2): 63. Https://Doi.Org/10.17509/Mimbar-Sd.V5i2.11444.

Misla, Misla, And Mawardi Mawardi. 2020. "Efektifitas Pbl Dan Problem Solving Siswa Sd Ditinjau Dari Kemampuan Berpikir Kritis." Jurnal Ilmiah Sekolah Dasar 4 (1): 60. Https://Doi.Org/10.23887/Jisd.V4i1.24279.

Mungzilina, Arista Khoirul, Firosalia Kristin, And Indri Anugraheni. 2018. "Penerapan Model Pembelajaran Problem Based Learning Untuk Meningkatkan Tanggung Jawab Dan Hasil Belajar Siswa Kelas 2 Sd." Naturalistic: Jurnal Kajian Penelitian Pendidikan Dan Pembelajaran 2 (2): 184-95. Https://Doi.Org/10.35568/Naturalistic.V2i2.209.

Nurhayati, Erlis. 2020. "Meningkatkan Keaktifan Siswa Dalam Pembelajaran Daring Melalui Media Game Edukasi Quiziz Pada Masa Pencegahan Penyebaran Covid-19.” Jurnal Paedagogy 7 (3): 145. Https://Doi.Org/10.33394/Jp.V7i3.2645.

Pramudya, Erviyanti, Firosalia Kristin, And Indri Anugraheni. 2019. "Peningkatan Keaktifan Dan Hasil Belajar Ipa Pada Pembelajaran Tematik Menggunakan Pbl." Naturalistic: Jurnal Kajian Penelitian Pendidikan Dan Pembelajaran 3 (2): 320-29. Https://Doi.Org/10.35568/Naturalistic.V3i2.391.

Prayogi, Rayinda Dwi, And Rio Estetika. 2019. "Kecakapan Abad 21 : Kompetensi Digital Pendidik Masa Depan." Jurnal Manajemen Pendidikan $14 \quad$ (2): $144-51$. Http://Journals.Ums.Ac.Id/Index.Php/Jmp/Article/Download/9486/5193.

Safitri, Ita, And Endang Endarini. 2020. "Efektivitas Model Problem Based Learning Dan Problem Posing Terhadap Kemampuan Pemecahan Masalah Di Sekolah Dasar." Jurnal Basicedu 4 (2): 412-18. Https://Doi.Org/10.31004/Basicedu.V4i2.366.

Siswa, Keaktifan Belajar. 2018. "Penerapan Model Problrm Based Learning ( Pbl ) Untuk Meningkatkan Keaktifan Belajar Dan Hasil Belajar Tema 8 Kelas V."

Slameto, Slameto. 2015. "Implementasi Penelitian Tindakan Kelas." Scholaria: Jurnal Pendidikan Dan Kebudayaan 5 (3): 47. Https://Doi.Org/10.24246/J.Scholaria.2015.V5.I3.P47-58.

Termini, End, F Project Description, Duportail Street, B Stip Id, Expenditure Schedule, Federal Fund Code, Federal Funds, Et Al. 2020. “No 主観的健康感を中心とした在宅高齢者における 健康関連指標に 関する共分散構造分析title” 21 (1): 1-9.

Vera, Monika, And Suhandi Astuti. 2019. "Peningkatan Kreativitas Dan Hasil Belajar Siswa Melalui Model Pembelajaran Problem Based Learning Pada Kelas Vsdn Sidorejo Lor V Salatiga." Monika Vera Mawardi Suhandi Astuti 6 (1): 11-21.

Wibowo, Nugroho. 2016. "Upaya Peningkatan Keaktifan Siswa Melalui Pembelajaran Berdasarkan Gaya Belajar Di Smk Negeri 1 Saptosari." Elinvo (Electronics, Informatics, And Vocational Education) 1 (2): 128-39. Https://Doi.Org/10.21831/Elinvo.V1i2.10621 